AGRICULTURE AND BIOLOGY JOURNAL OF NORTH AMERICA

ISSN Print: 2151-7517, ISSN Online: 2151-7525, doi:10.5251/abjna.2013.4.3.291.299

(C) 2013, ScienceHuß, http://www.scihub.org/ABJNA

\title{
An inventory of short horn grasshoppers in the Menoua Division, West Region of Cameroon
}

\author{
Seino RA ${ }^{1}$, Dongmo $\mathrm{TI}^{1}$, Ghogomu $\mathrm{RT}^{2}$, Kekeunou $\mathrm{S}^{3}$, Chifon $\mathrm{RN}^{1}$, Manjeli $\mathrm{Y}^{4}$ \\ ${ }^{1}$ Laboratory of Applied Ecology (LABEA), Department of Animal Biology, Faculty of Science, \\ University of Dschang, P.O. Box 353 Dschang, Cameroon, \\ ${ }^{2}$ Department of Plant Protection, Faculty of Agriculture and Agronomic Sciences (FASA), \\ University of Dschang, P.O. Box 222, Dschang, Cameroon. \\ ${ }^{3}$ Département de Biologie et Physiologie Animale, Faculté des Sciences, Université de \\ Yaoundé 1, Cameroun \\ 4 Department of Biotechnology and Animal Production, Faculty of Agriculture and Agronomic \\ Sciences (FASA), University of Dschang, P.O. Box 222, Dschang, Cameroon.
}

\begin{abstract}
The present study was carried out as a first documentation of short horn grasshoppers in the Menoua Division of Cameroon. A total of 1587 specimens were collected from six sites i.e. Dschang (265), Fokoue (253), Fongo - Tongo (267), Nkong - Ni (271), Penka Michel (268) and Santchou (263). Identification of these grasshoppers showed 28 species that included 22 Acrididae and 6 Pyrgomorphidae. The Acrididae belonged to 8 subfamilies (Acridinae, Catantopinae, Cyrtacanthacridinae, Eyprepocnemidinae, Oedipodinae, Oxyinae, Spathosterninae and Tropidopolinae) while the Pyrgomorphidae belonged to only one subfamily (Pyrgomorphinae). The Catantopinae (Acrididae) showed the highest number of species while Oxyinae, Spathosterninae and Tropidopolinae showed only one species each. Ten Acrididae species (Acanthacris ruficornis, Anacatantops sp, Catantops melanostictus, Coryphosima stenoptera, Cyrtacanthacris aeruginosa, Eyprepocnemis noxia, Gastrimargus africanus, Heteropternis sp, Ornithacris turbida, and Trilophidia conturbata ) and one Pyrgomorphidae (Zonocerus variegatus) were collected in all the six sites. Twelve Acrididae and 3 Pyrgomorphidae were collected during the wet and dry seasons. The importance of these grasshoppers in relation to pest activity, necrophagy, entomophagy, and entomotherapy, are discussed.
\end{abstract}

\section{INTRODUCTION}

For several centuries the problems posed by pest grasshoppers has attracted a lot of attention for biological studies and control. It is also very evident from literature that short horn (acridid) grasshoppers leave no doubt that they are the most renowned enemies of man since the advent of agriculture. Of recent, the conservation of grasshopper species is taking centre stage.

The Menoua Division is geographically located between $5^{\circ}-5.5^{\circ}$ latitude north and $9.4^{\circ}$ to $10.25^{\circ}$ longitude east on the map of the world in the West Region of Cameroon. This division spreads from Santchou (altitude 600m) to the Nkong- Ni (Djuttitsa) plateau at an altitude of $2200 \mathrm{~m}$. The climate is tropical - cold in a large part of the division. Average annual temperatures (from 1997 -2006) were $25.35^{\circ} \mathrm{C}$
(Maximum) to $13.66^{\circ} \mathrm{C}$ (Minimum) and the average annual rainfall for the same period was $1717.7 \mathrm{~mm}$. These climatic attributes and the soil texture confer on the Menoua Division an excellent agricultural zone for the cultivation of both food and cash crops. It is for this reason that the Menoua Division is considered one of the important bread baskets of Cameroon. The important agricultural and horticultural plants include coffee, tea, plantains, Irish potato, sweet potato, maize, cassava, pear, mango, guava and beans (Délégation Department d' Agriculture, 2011). The agricultural activities of the Menoua Division involve the use of fertilizers and pesticides that are likely to have drastic affects on the grasshopper populations.

Cameroon is host to many species of short - horned grasshoppers but this acridid fauna has been subject 
of very little study and their biodiversity is little known. A review of the catalogue of short-horn grasshoppers in Cameroon (Mestre and Chiffaud, 2009) revealed the presence of 240 Acridid grasshopper species in Cameroon of which the Caelifera comprised 6 families that included Chorotypidae (7 species), Thericleidae (5 species), Euschmidtiidae (2 species), Pyrgomorphidae (16 species), Pamphagidae (0 species) and Acrididae (210 species). The Acrididae is the largest of the five families with 210 species represented while Thericleidae is the smallest family with only five species represented. The Pamphagidae is not represented in Cameroon.

The importance of short horn grasshoppers in our environment cannot be overemphasized. Short-horn grasshoppers form important links in food chains (Verma and Agarwal, 2005). In several regions they are useful indicators of environmental change because of their diverse ecological characteristics and requirements (Wettstein and Schmid, 1999; Anderson et al, 2001). Short horn grasshoppers exhibit entomophagy with several species serving as a good sources of protein to humans and laboratory animals (Ladeji et al, 2003; Banjo et al, 2000; Ronghang and Ahmed, 2010; Chakravorty et al, 2011). Though short horn grasshoppers have been considered archeptypical herbivores that primarily feed on leaves of living plants (Chapman, 1990) several have been found to be omnivorous and exhibit necrophagy (Whitman and Richardson, 2010). The use of short horn grasshoppers as food (Entomotherapy) and in traditional medicine (Entomotherapy) in China and India have been variously reported in literature (Chakravorty et al, 2011, Doley and Kalita, 2012). However, information is scarce in literature on entomophagy and entomotherapy of short horn grasshoppers in Africa and Cameroon in particular. Most importantly, the great majority of sholert-horn grasshoppers are pests or potential pests of agricultural importance (Benkenana and Harrat, 2009) and in some regions they determine between live and starvation. Since we know that certain non gregarious acridids and hence habitually non pest species such as Eyprepocnemis plorans Ocnerida volxemii, Calliptamus barbarus and Calliptamus wattenwylianus can in certain years become veritable pests (Benharzallahy, 2011), detailed knowledge of the biodiversity, systematics and ecology of short horn grasshoppers of any region will be of help to prevent crop damage. It is in this perspective that we are interested in the short horn grasshopper species of the Menoua Division in the West Region of Cameroon.
The general factors that influence species diversity in terrestrial ecosystem include climate (Currie, 1991), habitat structure and productivity (Morris, 1990; Rosenzweig and Abramsky, 1993) and biogeographical factors such as habitat area and isolation (Connor and McCoy, 1979). All these factors are being increasingly influenced by human activities in the Menoua Division of Cameroon. In addition, it is expected that global warming reported to have significant consequences for the distribution of species and the composition of communities along gradients of temperatures (Root, 1993; Guisan et al, 1995) would similarly affect short horn grasshopper fauna in Cameroon. Furthermore changes in agricultural practices that directly modifying habitat quality is common to the Menoua Division of Cameroon. This article is expected to help create awareness among farmers, agriculturist, students, teachers and researchers of the potentials presented by the short-horn grasshopper fauna in the Menoua Division of Cameroon.

In Cameroon, the composition and dynamics of grasshopper assemblages are extremely poorly understood. This article was designed to describe in detail the biodiversity of short - horn grasshoppers, with the view to present a list of short horn grasshoppers, identify pest and potential pest species as well as species that could possibly be used as food and in traditional medicine in the Menoua Division, West Region of Cameroon.

\section{MATERIALS AND METHODS}

The study was conducted to collect short-horn grasshoppers in the Menoua Division, in the West Region of Cameroon (Fig. 1) from January 2011 to December 2012. The study area was divided into six collection sites that included Santchou, Dschang, Fongo-Tongo, Nkong-Ni, Fokoue and Penka Michel. Insects were collected from 10 fields or farms selected randomly from each collection site making sure that they were separated from each other by at least $2 \mathrm{Km}$. This permitted us to practically cover the total study area. The grasshoppers were collected with the help of sweep-nets and by hand picking. Each collection site was visited twice a month and the insects collected were transported to the laboratory in bottle-cages prepared with the method of Popov (1990).

On arrival at the laboratory, adult insects were sorted out, killed in a death chamber provided with Ethyl Acetate and then properly spread before drying in an oven at $60^{\circ} \mathrm{C}$ for 48 hours. Photographs were taken 
using a kodack Easy Share C143 digital camera with a 12 mega pixels lens.

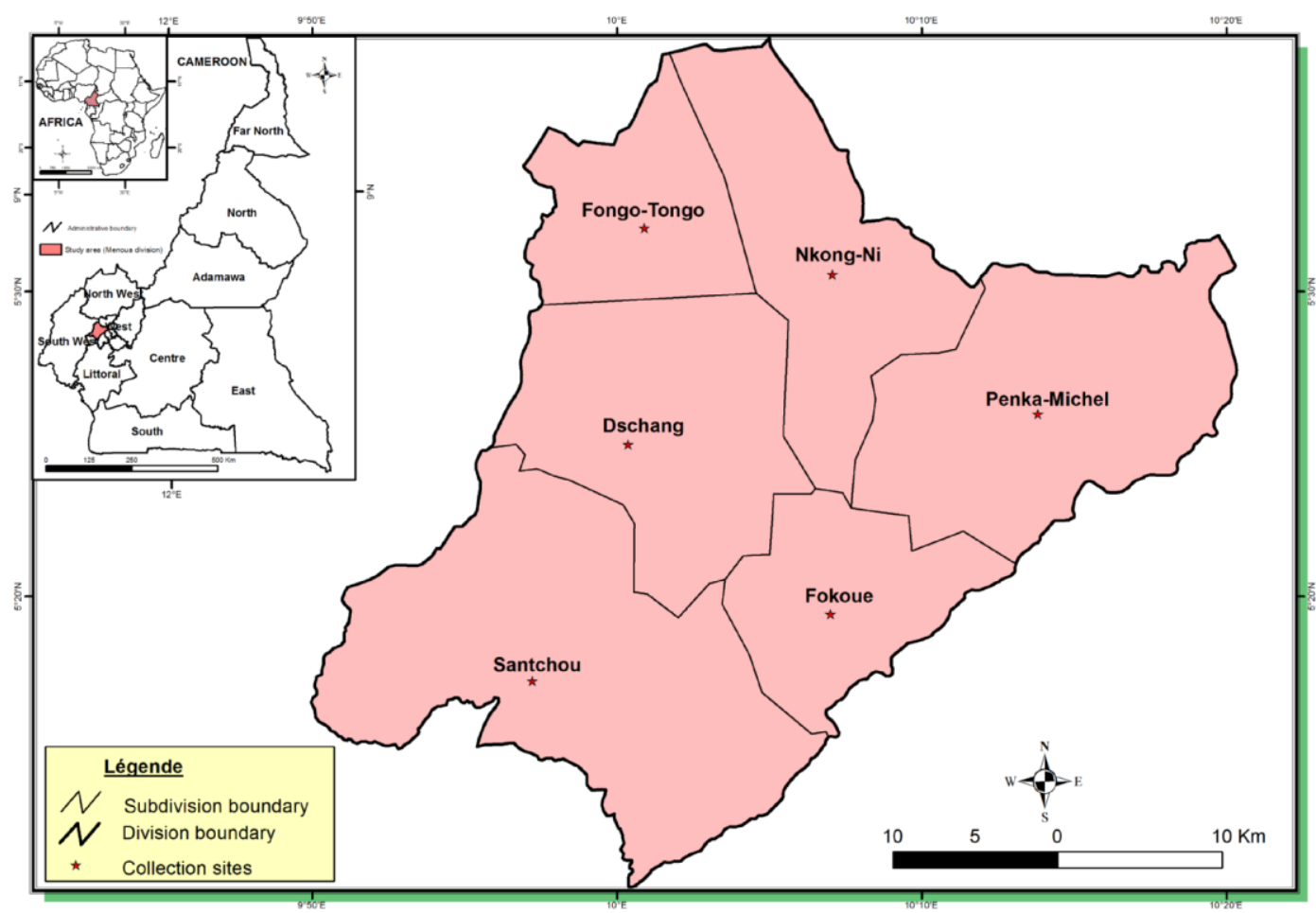

Fig1: Map of the study area

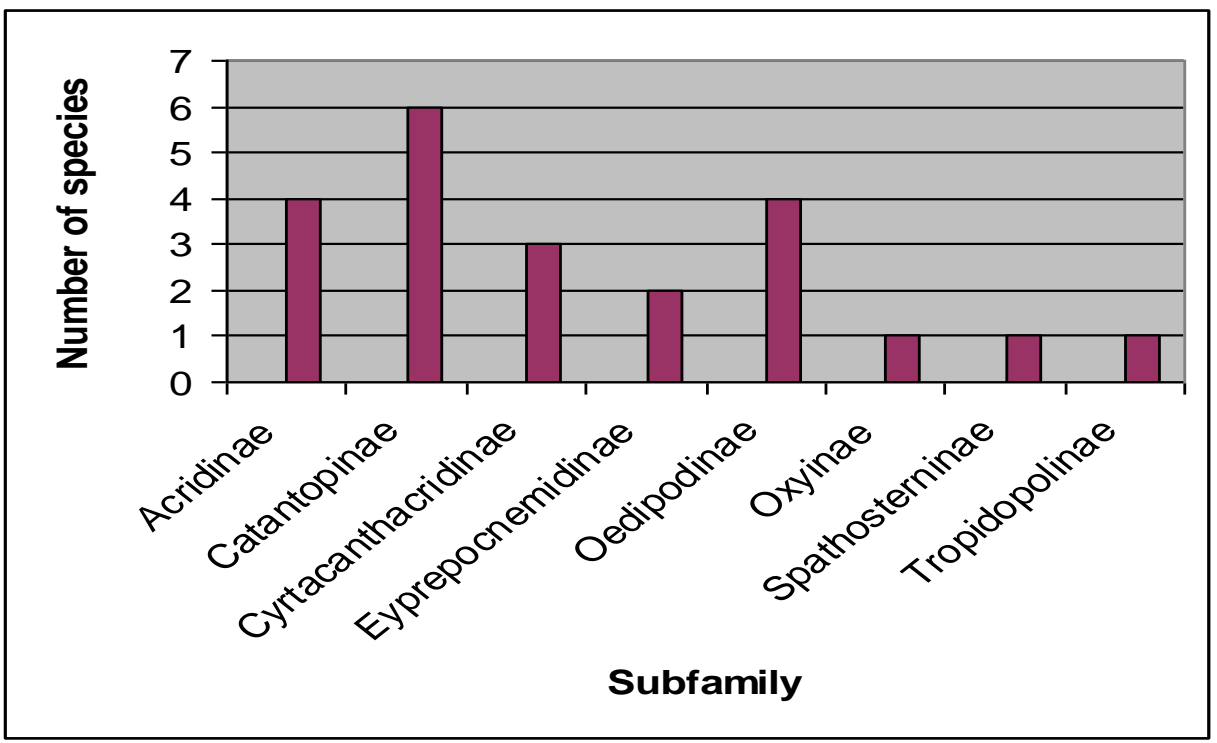

Fig. 2: Number of species collected in the different Acrididae subfamilies represented in the Menoua Division of the West Region of Cameroon from January 2011 to December 2012. 


\section{AGRICULTURE AND BIOLOGY JOURNAL OF NORTH AMERICA}

ISSN Print: 2151-7517, ISSN Online: 2151-7525, doi:10.5251/abjna.2013.4.3.291.299

(C) 2013, ScienceHu $\beta$, http://www.scihub.org/ABJNA

The specimens were identified by carrying out detailed study of morphological characters. Measurements of the length of the head, the length and height of the pronotum, the length of elytra, and the length of the femur and meta-thoracic leg were made with the help of an electronic a vernia calliper. Other morphological characters that were used during the identification included especially the position of the auditory opening, the tympanic organ, the type of ovipositor, and stridulatory organ. Identification keys used to recognise the species came from Dirsh, (1975); Launois, (1978); Lecoq, (1988); and Mestre and Chiffaud, (1988, 2009).

Identified insects were next mounted in insect storage boxes, labelled with scientific names, place and date of collection. Each box was supplied with
Naphthalene balls to protect the specimens from insect pests and then deposited in the Museum of the Department Animal Biology, University of Dschang for future references.

\section{RESULTS}

Of the 1587 specimens collected from the six collection sites in the Menoua Division of Cameroon, a total of 28 short-horn grasshopper species were identified. Details of the inventory of the short horn grasshoppers are shown in Table 1. These species belonged to the families Acrididae and Pyrgomorphidae. Of these, 22 belonged to the Acrididae and 6 to the Pyrgomorphidae. Therefore the Acrididae family was better represented in number of species.

Table 1: List of short-horn grasshopper species recorded at the study sites in the Menoua Division in the West Region of Cameroon from January 2011 to December 2012.

\begin{tabular}{|c|c|c|}
\hline FAMILY & SUB-FAMILY & SPECIES \\
\hline \multirow{22}{*}{ ACRIDIDAE } & \multirow{4}{*}{ ACRIDINAE } & Acrida turrita \\
\hline & & Amphicremna scalata \\
\hline & & Coryphosima stenoptera \\
\hline & & Parga cyanoptera \\
\hline & \multirow{6}{*}{ CATANTOPINAE } & Abisares viridipennis \\
\hline & & Anacatantops sp. \\
\hline & & Catantops melanostictus \\
\hline & & Serpusia sp. \\
\hline & & Sternocrobylus festivus \\
\hline & & Oxycatantops spissus \\
\hline & \multirow[t]{3}{*}{ CYRTACANTHACRIDINAE } & Acanthacris ruficornis \\
\hline & & Cyrtacanthacris aeruginosa \\
\hline & & Ornithacris turbida \\
\hline & \multirow[t]{2}{*}{ EYPREPOCNEMIDINAE } & Eyprepocnemis noxia \\
\hline & & Eyprepocnemis plorans \\
\hline & \multirow{4}{*}{ OEDIPODINAE } & Gastrimargus africanus \\
\hline & & Heteropternis $s p$. \\
\hline & & Morphacris fasciata \\
\hline & & Trilophidia conturbata \\
\hline & OXYINAE & Oxya hyla \\
\hline & SPATHOSTERNINAE & Spathosternum pygmaeum \\
\hline & TROPIDOPOLINAE & Afroxyrrhepes obscuripes \\
\hline \multirow{6}{*}{ PYRGOMORPHIDAE } & \multirow{6}{*}{ Pyrgomorphinae } & Atractomorpha lata \\
\hline & & Chrotogonus senegalensis \\
\hline & & Dictyophorus griseus \\
\hline & & Pyrgomorpha vignaudii \\
\hline & & Taphronota thaelephora \\
\hline & & Zonocerus variegatus \\
\hline
\end{tabular}

Anacatantops sp., Catantops melanostictus, Cyrtacanthacris aeruginosa, Eyprepocnemis noxia, Gastrimargus africanus, Heteropternis sp.,
Ornithacris turbida, Trilophidia conturbata (Acrididae), and Zonocerus variegatus(Pyrgomorphidae) were collected in all six 
collection sites. Acrida turrita, Afroxyrrhepes obscuripes, Serpusia sp and Sternocrobylus festivus (Acrididae) and Chrotogonus senegalensis, and
Pyrgomorpha vignaudii (Pyrgomorphidae) were very rare being collected from only one of the collection sites (Table 2).

Table 2: Species of short-horn grasshoppers recorded from different localities in the Menoua Division in the West Region of Cameroon from January 2011 to December 2012. + = present; - = absent

\begin{tabular}{|c|c|c|c|c|c|c|}
\hline \multirow[t]{2}{*}{ Species } & \multicolumn{6}{|c|}{ Localities of collection } \\
\hline & Dschang & Fokoue & Fongo-Tongo & Nkong-Ni & $\begin{array}{l}\text { Penka- } \\
\text { Michel }\end{array}$ & Santchou \\
\hline \multicolumn{7}{|c|}{ ACRIDIDAE } \\
\hline Abisares viridipennis & - & + & + & - & + & - \\
\hline Acanthacris ruficornis & + & + & + & + & + & + \\
\hline Acrida turrita & - & - & - & - & - & + \\
\hline Afroxyrrhepes obscuripes & - & - & + & - & - & - \\
\hline Amphicremna scalata & - & - & - & - & - & + \\
\hline Anacatantops sp. & + & + & + & + & + & + \\
\hline Catantops melanostictus & + & + & + & + & + & + \\
\hline Coryphosima stenoptera & + & + & + & + & + & + \\
\hline Cyrtacanthacris aeruginosa & + & + & + & + & + & + \\
\hline Eyprepocnemis noxia & + & + & + & + & + & + \\
\hline Eyprepocnemis plorans & - & + & + & + & + & - \\
\hline Gastrimargus africanus & + & + & + & + & + & + \\
\hline Heteropternis sp. & + & + & + & + & + & + \\
\hline Morphacris fasciata & - & - & + & + & - & - \\
\hline Ornithacris turbida & + & + & + & + & + & + \\
\hline Oxya hyla & + & - & - & + & + & + \\
\hline Oxycatantops spissus & - & - & - & - & - & + \\
\hline Parga cyanoptera & - & - & - & - & - & + \\
\hline Serpusia sp & + & - & - & - & - & - \\
\hline Spathosternum pygmaeum & + & - & - & + & - & + \\
\hline Sternocrobylus festivus & - & - & - & + & - & - \\
\hline Trilophidia conturbata & + & + & + & + & + & + \\
\hline \multicolumn{7}{|c|}{ PYRGOMORPHIDAE } \\
\hline Atractomorpha lata & + & - & - & - & - & + \\
\hline Chrotogonus senegalensis & + & - & - & - & - & - \\
\hline Dictyophorus griseus & + & - & - & - & - & - \\
\hline Pyrgomorpha vignaudii & + & - & - & - & - & - \\
\hline Taphronota Thaelephora & - & - & - & + & + & - \\
\hline Zonocerus variegatus & + & + & + & + & + & + \\
\hline
\end{tabular}

As reflected in Table 3 Anacatantops sp., Acanthacris ruficornis, Catantops melanostictus, Coryphosima stenoptera, Oxycatantops spissus, Cyrtacanthacris aeruginosa, Eyprepocnemis noxia, Heteropternis sp., Gastrimargus africanus , Morphacris fasciata , Ornithacris turbida and Trilophidia conturbata (Acrididae). The following Pyrgomorphidae were commonly found in both the dry and wet seasons
Atractomorpha lata, Taphronota thaelephora and Zonocerus variegatus. Afroxyrrhepes obscuripes and Sternocrobylus festivus (Acrididae) were exclusively dry season while Abisares viridipennis, Acrida turrita, Amphicremna scalata, Eyprepocnemis plorans, Oxya hyla, Serpusia $s p$ and Spathosternum pygmaeum (Acrididae) and Chrotogonus senegalensis, 
Dictyophorus griseus and Pyrgomorpha vignaudii

(Pyrgomorphidae), were strictly wet season.

Table 3: Species of short-horn grasshoppers recorded in the dry and wet seasons in different localities of the Menoua Division in the West Region of Cameroon from January 2011 to December 2012. + = present; - = absent

\begin{tabular}{|c|c|c|}
\hline \multirow[t]{2}{*}{ Species } & \multicolumn{2}{|c|}{ Season of collection } \\
\hline & Dry & Wet \\
\hline \multicolumn{3}{|c|}{ ACRIDIDAE } \\
\hline Abisares viridipennis & - & + \\
\hline Acanthacris ruficornis & + & + \\
\hline Acrida turrita & - & + \\
\hline Afroxyrrhepes obscuripes & + & - \\
\hline Amphicremna scalata & - & + \\
\hline Anacatantops sp. & + & + \\
\hline Catantops melanostictus & + & + \\
\hline Cyrtacanthacris aeruginosa & + & + \\
\hline Coryphosima stenoptera & + & + \\
\hline Eyprepocnemis noxia & + & + \\
\hline Eyprepocnemis plorans & - & + \\
\hline Gastrimargus africanus & + & + \\
\hline Heteropternis sp. & + & + \\
\hline Morphacris fasciata & + & + \\
\hline Ornithacris turbida & + & + \\
\hline Oxya hyla & - & + \\
\hline Oxycatantops spissus & + & + \\
\hline Parga cyanoptera & - & + \\
\hline Serpusia sp & - & + \\
\hline Spathosternum pygmaeum & - & + \\
\hline Sternocrobylus festivus & + & - \\
\hline Trilophidia conturbata & + & + \\
\hline \multicolumn{3}{|c|}{ PYRGOMORPHIDAE } \\
\hline Atractomorpha lata & + & + \\
\hline Chrotogonus senegalensis & - & + \\
\hline Dictyophorus griseus & - & + \\
\hline Pyrgomorpha vignaudii & - & + \\
\hline Taphronota Thaelephora & + & + \\
\hline Zonocerus variegatus & + & + \\
\hline
\end{tabular}

\section{DISCUSSIONS}

Grasshoppers are a dominant group of herbivorous insects throughout the world and their high diversity, functional importance, sensitivity to disturbance and ease of sampling makes them potentially useful bioindicators for land management. In Cameroon, the dynamics of grasshopper assemblages are extremely poorly understood. The survey of the short-horn grasshoppers of the Menoua Division in the West Region of Cameroon was carried during a period of two years from January 2011 to December 2012 to complement and confirm information on the Cameroonian fauna. The present study is among the first documented reports for surveying short-horn grasshoppers in this Division of Cameroon. During the survey a total of 1587 specimens were collected from six sites and identification of these specimens showed that 22 of them belonged to the Acrididae and 6 to the Pyrgomorphidae. The 22 Acrididae grasshoppers could be separated into 8 subfamilies and 21 genera while the 6 Pyrgomorphidae could be grouped into one subfamily and 6 genera. 
Two of the short-horn grasshoppers identified in this study are well known pest species in Cameroon. Some others are potential pest species. Zonocerus variegatus (Pyrgomorphidae) identified in this study is a pest of immense agricultural importance in Cameroon and several other African countries. This species is polyphagous feeding on a wide variety of wild and cultivated plants (Toye, 1982, Chapman et al, 1986). Due to the high damage it inflicts on crops, $Z$. variegatus is considered an important agricultural pest in Nigeria (Iduwu and Modder, 1996); Ivory Coast (Chapman et al.,1986); Ghana (Modder, 1994); Congo Brazzaville (Bani, 1990); and in the Sahel (Abou-thiam,1991). This short - horn grasshopper is currently classified as the most important grasshopper pests for both food and cash crops in the Humid Forest Zone of Cameroon (Keukenou et al., 2006; Messi et al., 2006). Taphronota thaelephora (Pyrgomorphidae) has been reported as pest in Cameroon though of minor economic status. Nonvieller (1984) reported $T$. thaelephora as a pest of coffee in the West and Centre Regions of Cameroon. This grasshopper has been shown in the laboratory to be polyphagous and to feed on more than ten food and cash crop plants commonly cultivated in the West Region of Cameroon (Seino et al., 2001). Atractomorpha lata is a known pest of rice in the Asian continent (Kobayashi et al., 1972) and is also pest to over 132 medicinal plant species (Lee et al., 2007). This shorthorn grasshopper is therefore a potential pest in Cameroon and needs to be monitored. Eyprepocnemis plorans has been observed to attack food crops in Algeria and cause important damage during certain years (Benharzallah, 2011). This short horn grasshopper could therefore be considered a potential pest species in Cameroon and needs to be monitored.

Grasshoppers have been shown to be good sources of protein and minerals for humans and laboratory animals. $Z$. variegatus is widely consumed in Northern and South-West Nigeria and it is known for its high crude protein and mineral content (Ladeji et al, 2003). This species has been shown to be a good supplement in the feed for albino laboratory rats (Ogunleye and Omotoso, 2005). Entomophagy of short horn grasshoppers in Cameroon is yet to be investigated even though short horn grasshoppers are widely eaten in the West and North West regions of the Country.

Several Orthoptera are implicated in carnivory / necrophagy (Whitman et al, 1994; Whitman and
Richardson, 2010; Feugang et al, 2012) an activity that is important in the disposal of dead organic waste from the environment. These grasshoppers have been reported to feed on dead organic matter such as their siblings, other insects, mushrooms, vertebrate faeces, invertebrate faeces, linen, silk and even wool on live sheep (Whitman and Richardson, 2010). Short horn grasshoppers such as Schistocerca gregaria (Acrididae Cyrtacanthacridinae), Melanoplus foedus (Acrididae -Acridinae) and Taneniopoda eques ( Acrididae Romaleinae) have been shown to be carnivorous/ necrophagous (Whitman and Richardson, 2010). None of the short horn species collected in the Menoua division has been shown to be carnivorous. However, some of them are potential carnivores since they occur in the same families and subfamilies of known necrophagous grasshoppers.

The use of insects and insect products in traditional medicine is known worldwide. However, information on the use of grasshoppers in traditional medicine is available only for Chinese and Indian culture (Doley and Kalita, 2012). Literature is grossly lacking for Africa and in particular Cameroon. Memebers of Acrididae - Cyrtacanthacridinae have been implicated elsewhere, Acrididae - (Chakravorty et al, 2011; Doley and Kalita, 2012). So far only the family Acrididae has been implicated in the therapeutic uses of short horn grasshoppers.

\section{CONCLUSION}

The shorthorn grasshopper fauna in the Menoua division of Cameroon is highly diversified and made up of more than 28 species. This fauna includes well known pest species such as $Z$. variegatus and $T$. thaelephora as well as several potential pest species. Potentials exist for exploitation of these grasshoppers for food and traditional medicine. Therefore need arises for consideration of conservation strategies. It is recommended that similar surveys should be conducted on large scale in other Divisions so as to fully evaluate the acridid fauna of the West Region of Cameroon. Proper measure should be taken to minimize the chances of disturbances and loss of natural habitats as it would adversely affects the composition and abundance of acridid community.

\section{ACKNOWLEDGEMENTS}

We are grateful to Professor MPOAME Mbida, Head of the Applied Ecology Laboratory (LABEA) in the Department of Animal Biology, Faculty of Science, of the University of Dschang for providing the space used for this study. 


\section{REFERENCES}

Abou-thiam. 1991. Problematique de l'utilisation des insecticides chimiques dans la lutte anti-acridien. In « la lutte anti-acridien » AUPELF-UREF : John Libbey Rurotext, Paris, 1991 : 193 - 206.

Anderson AN. Ludwig JA. Lowe LM. Rentz CF. 2001. Grasshopper biodiversity and bioindicators in Australian tropical savannas: Responses to disturbance in Kakadu National Park. Australian Ecology, 26: $213-222$.

Banjo AD, Lawal OA, Songonuga EA, 2006. The nutritional value of fourteen species of edible insects in Southwestern Nigeria. African journal of Biotechnology, 5 (3): 298 - 301

Bani G. 1990. Stratégie de lutte contre le criquet puant, Zonocerus variegatus (Orthoptera: Pyrgomorphidae) au Congo. Journal of African Zoology, 104: 69 - 76.

Benharzallah N, 2011. Inventaire et bio-ecologie des acridiens dans deux etages bio-climatiques differents (Aride et Semi-Aride). Actes du Seminaire International sur la Biodiversité Faunistique en Zone Arides et Semi-arides.

Benkenana N, and Harrat A, 2009. Contribution to the systematic study of grasshopper fauna (Orthoptera, Califera) and some bioecological aspects of economic importance of species in the Constantine region (Eastern Algeria). Emir. J. Food Agric. 21 (1): 40 - 47

Chakravoty J, Ghosh S, Meyer-Rochow VB, 2011. Practices of entomophagy and entomotherapy by members of the nyishi and Galo tribes, two ethnic groups of the State of Arunachal Pradesh (North East India). Journal of ethnobiology and Ethnomedicine, 7:5

Chapman RF. Page WW. Cook AG. 1986. Bionomics of the variegated grasshopper (Zonocerus variegatus) in West and Central Africa. Annual Review entomology, 31: $479-505$.

Chapman RF. 1990. Food selection , pp. 39 - 72. In Chapman R.F., Joern A. (Eds) Biology of grasshoppers. John Wiley \& Sons, New York

Connor EF. McCoy ED. 1979. The statistics and biology of the species-area relationship .American Naturalist 113: $791-833$.

Curie DJ. 1991. Energy and large scale patterns of animal and plant species richness. American Naturalist, 137: $27-49$.

Délégation Départementale d'Agriculture. 2011. Rapport Annuel D'activités de l'Agriculture et du Développement rural de la Menoua.

Dirsh DVM. 1975. The classification of Acridomorphoid insects. E.W. Cassey Ltd: Farrington Oxon, pp. 1 171.
Doley AK, and Kalita J, 2012. Traditional use of insect and insect products in medicine and food by the Mishing tribe of Dhemaji District, Assam, North -East India. Social Science Researcher, 1.2: $11-21$

Ghosh AK and Sengupta T. 1982. Handbook on insect collection, preservation and study. Handbook series, Zoological survey of India, Kolkata. P.64

Guisan A. Tessier I. Holten Jl. Haeberli W. Baumgartner. 1995. Understanding the impact of climate change on mountain ecosystem: an overview. Potential Ecological Impacts of Climate Change in the Alps and Fennoscandian Mountains (ed. A. Guisan). Pp. 15 37. Conservatoire et Jardin Botanique, Genève.

Iduwu AB. Modder WWD. 1996. Possible control of the stinking grasshopper, Zonocerus variegatus (L) (Orthoptera: Pyrgomorphidae) in Ondo State, through human consumption. The Nigerian Field, 61: 7 - 14.

Kekeunou S. Wiese S. Messi J. Tamo M. 2006. Farmers' perception on the importance of variegated grasshopper (Zonocerus variegatus (L)) in the agricultural production system of the humid forest zone of southern Cameroon. Journal of Ethnobiology and Ethnomedicine, 2(17): 1 -12.

Kobayashi T. Hasegawa T. Kegasawa K. 1972. Major insect pests of leguminous crops in Japan. Trop. Agric. Res. Ser., Japan, $6: 109-126$.

Ladeji O. Solomon M. Maduka H. 2003. Proximate chemical analysis of Zonocerus variegatus (Giant grasshopper). Nigerian Journal of Biotechnology, 14(1): 42 - 45

Launois M. 1978. Manuel pratique d'identification des principaux acridiens du Sahel Ministère de la coopération de CERDAT, Paris. 303P.

Lecoq M. 1988. «Les criquets du sahel ». Ed. PRIFAS, Montpellier, Coll. Acrid. Opér. (1), 129p.

Lee DW. Park JC. Kim DS. Kim CS. Choo HY. 2007. Kinds and occurring time of insect pests in medicinal plant Http://agris.fao.org/aos/records/KR2008003318.

Messi J. Kekeunou S. Weisse S. 2006. Abundance and life cycle of Zonocerus variegatus (L) (Orthoptera: Pyrgomorphidae) in the humid forest zone of southern Cameroon. Entomological Science, $9: 23-30$.

Mestre j. Chiffaud J. 2009. Catalogue et atlas des acridiens d'Afrique de l'Ouest 265 Orthoptera species file (OSF). 2011. http://orthoptera.speciesfile.org

Mestre j. Chiffaud J. 1988. Les Acridiens des formations herbeuses D'Afrique de l'Ouest. CIRAD - PRIFAS, Département GERDAT.Montpellier France

Morris MG. 1990. The Hemiptera of two sown calcareous grasslands. II. Differences between treatments. Journal of Applied Ecology, 27: 379 - 393 
Nonvieller GV. 1984. Catalogue des insects du Cameroun d'intérêt agricole. PRIFAS Montpellier. 210pp.

Ogunleye RF, Omotoso OT, 2005. Edible Orthopteran and Lepidopteran as protein substitutes in the feeding of experimental albino rats. African Journal of Applied Zoology and Environmental Biology, 7: 48 - 51

Popov GB. 1990. Raising locusts and obtaining egg-pods: A simple method. Surveillance Acridien au Sahel, 15.

Ronghang R, and Ahmed R. 2010. Edible insects and their conservation strategy in Karbi Anglong District of Assam, North East India. The Bioscan, special Issue, 2: $515-521$.

Root TL. 1993. Effects of global climate change on North American birds and their communities. Biotic interactions and Global change (eds P.m. Kareiva, J.g. Kingsolver \& R.b; Huey), pp. 9 - 23.Sinauer Associates Inc. Sunderland, Massachusetts

Rosenzweig ML. Abramsky Z. 1993. How are productivity and diversity related? Species diversity in ecological communities.

Historicxaland

Geographical
Perspectives (eds E.r. Ricklefs \& D. Schluter), pp. 52 65. Chicago University Press, Chicago.

Seino RA. Mpoame M. Nembot E. 2001. Observations on the food preferences of Taphronota thaelephora Stal. (Orthoptera: Pyrgomorphidae). J. Sci. and Environ. 1: $29-134$.

Toye SA. 1982. Studies on the biology of the grasshopper pest Zonocerus variegatus (L.) (Orthoptera: Pyrgomorphidae) in Nigeria: 1911 - 1981. International Journal of Tropical Insect Science, 3(1): 1 - 7

Verma PS. Agarwal VK. 2005. Cell Biology, Molecular Biology, Evolution and Ecology. S Chand \& Company Ltd. Ram Nagar, New Delhi 110055.

Wettstein W. Schmid B. 1999. Conservation of Arthropod diversity in montane wetlands: effecdt of altitude, habitat quality and habitat fragmentation on butterflies and grasshoppers. Journal of Applied Ecology, 36(3): $363-373$.

Whitman DW. Richardson ML. 2010. Necrophagy in grasshoppers: Taeniopoda eques feeds on mammal carrion. JOR, 19 (2): $377-380$. 